\title{
The US Economy, Global Imbalances and Recent Development: A Critical Review
}

\author{
Kalim SIDDIQUI ${ }^{1} \odot$
}

\begin{abstract}
The United States has been running deficits on current accounts since the early 1990s. The current account deficits and surplus have caused dislocations in both developing and advanced economies. A recent study by Bullard et al. (2017) noted that the US economy is still the world's largest economy and, according to the authors, between 2008-15 there was an average annual shortfall of $20 \%$ in fixed capital investment due to the 2008 crisis which also adversely impacted GDP growth and output (Bullard et al., 2017). This study will discuss the recent development in the US economy and also global imbalances in a historical perspective in order to try to understand the current situation. The discussion also includes the recent rise in China's economy and the international trade. The study concludes that the trade deficits on the current scale cannot continue forever. Closing the trade deficit will require a more equal distribution of world spending, meaning a fall in US spending and a rise in spending from the rest of the world. Policy measures should be taken to increase state spending rather than rely on debt-fuelled private consumption to resolve inadequate aggregate demands. The reform should be made so as to seek profits in the real economy rather than 'finance financing finance'. Finance should be made less globalised.
\end{abstract}

Keywords: Global imbalances, Capitalism, Neoliberalism, US, China and instability

JEL Classification: E50, 60, F30, G15
'Dr., Senior Lecturer in Economics, Department of Accounting, Finance and Economics, Huddersfield Business School - University of Huddersfield, Huddersfield, UK

ORCID: K.S. 0000-0002-7952-4573

\section{Corresponding author/Sorumlu yazar:} Kalim SIDDIQUI,

Dr., Senior Lecturer in Economics, Department of Accounting, Finance and Economics, Huddersfield Business School - University of Huddersfield, Huddersfield, UK

E-mail/E-posta: Siddiqui@hud.ac.uk

Submitted/Başvuru: 09.12.2019

Accepted/Kabul: 18.12.2019

Citation/Atıf: Siddiqui, K. (2019). The US economy, global imbalances and recent development: A critical review. Istanbul iktisat Dergisi - Istanbul Journal of Economics, 69(2), 175-205.

https://doi.org/10.26650/ISTJECON2019-0027 


\section{Introduction}

This study will critically examine the structural causes of economic imbalances, particularly the high current account deficit of the United States. Correcting the current imbalances requires recognising the underlying characteristics of an advanced capitalist economy, namely the US. It is important to study the US economy as it is the world's largest economy and also provides markets for the surplus savings of other countries. This is seen by critics as not being sustainable in the long term, who also point out that imbalances are the main factor causing uncertainty and hindering growth (McBride, 2017; Wolf, 2008a).

The US has been running deficits on current accounts since the early 1990s. The government deficit fell below zero during the lateryears of the Clinton Administration, then rose under the Bush Administration and has followed an upward trend since then. The current account deficits and surplus have caused dislocations in both developing and advanced economies. In the mid-1970s, global imbalances were effectively concentrated between oil exporter countries and oil importing countries. However, in recent years this has declined somewhat. As long as a country runs a current account deficit, it must sell assets to the rest of the world in order to finance a portion of its imports and international income payments (Wade, 2009).

A recent study by Bullard et al. (2017) notes that the US economy is still the world's largest economy and, according to the authors, between 2008-15 there was an average annual shortfall of $20 \%$ in fixed capital investment due to the 2008 crisis which also adversely impacted GDP growth and output (Bullard et al., 2017).

This study will discuss global imbalances in a historical perspective in order to try to understand the current situation. We analyse why global imbalances have been defined as external positions of systemically important economies that reflect distortions or entail risks for the global economy. This explains the underlying features of global imbalances. This definition also tells us that global imbalances give us a clear sign of inner disequilibria within large economies, and whose behaviour could be of relevance to the rest of the world. 


\section{Theoretical Issues}

Mainstream economists see the current account imbalances not as a source of potential instability but rather as the result of emerging economics objectives of increased accumulation and export-led growth. They argue that global imbalances should not be a source of worry. After the 1997 East Asian crisis, most Asian countries felt a strong desire to sharply increase their US dollar reserve holdings. As a result, US dollar reserves were increased, leading to inefficiency. The assumption that an open economy with automatic capital flows will offset balanceof-payments imbalances and that are largely made up of major flows of productive investment that only exist in economic textbooks. In the real world, speculative flows constitute large proportions of investment in the developing countries, and confer a volatility on exchange rates which robs them of any meaningful long-term investment.

Under such circumstances, Keynes (1980) argued that a greater burden lies on countries with surplus. According to Keynes, "The objective of the new system must be to require the chief initiative from the creditor countries, whilst maintaining enough discipline in the debtor countries to prevent them from exploiting the new ease allowed them in living profligately beyond their means" (Keynes, 1980, p. 30). Keynes (1973), in his book The General Theory, noted that the main concern during the Great Depression was to get capitalism out of its crisis, which required governments to regulate the market. He clearly acknowledged that his intention was to save the capitalist system and his macroeconomic analysis, in which the national product was composed of consumption and investments. The former is stable while the latter is unpredictable. According to Keynes, hoarding and the speculation prevents capitalism from working in an ideal manner. During the crisis, consumption and investment have to be increased and if private investment is lacking then the government has to take the initiative. He also favoured the regulation of financial markets. For Keynes, the main cause of the economic crisis was due to reduced investments. However, if capitalists adopt a rational plan to increase production by increasing the level of investment, in the long run this is fine. However, if their 
decision is to stop this process, then this could result in a recession. An increase in investments leads to a rise in GDP. The capitalist's aim is to raise profits and accumulate more wealth. This could be achieved by raising productivity and, sometimes, by cutting wages. However, these policies could ultimately mean lower demand and reduce production capacities.

The question arises as to why the neoliberal model is retained once normality is restored, as happened after the 2008 financial crisis. The state assumes a greater role only for very short period, namely when the severe economic crisis forces the pace of change of economic policy. For instance, neoliberal capitalism was discredited after the Second World War, where the state acts merely as facilitator and adopts a regulatory role towards the economy, otherwise known as the Keynesian model, with more societal regulation, particularly in finance and labour welfare, and subsequently becomes involved in structural change that includes coordinating investment decisions, with the intention of protecting individuals against risks. The answer seems to be to do with the class nature of the state and the ruling elites like to keep the private ownership of the property.

The global financial crisis of 2008 showed weaknesses in capitalism and also its neoliberal policies, which were unable to resolve the crisis. The monetary system, under the neoliberal model, has contributed to global financial instability and has ultimately adversely affected the global economy. For developing countries, which heavily rely on trade and capital inflows for their economic growth, the failure of the global reserve system and the associated lack of international liquidity led to difficulties in the aftermath of the global financial crisis (Ghosh, 2018).

The question arises as to why, in recent years, the US economy has created huge deficits. And the US households have also accumulated huge debts to finance their consumption. On this issue, Wolf notes: "[A] country that receives a huge and sustained inflow of foreign lending runs the risk of a subsequent financial crisis because external and domestic financial fragility will grow ... Cheap money encouraged an orgy of financial innovation, borrowing and spending" (Wolf, 2008a, p. 13). 
Certainly, easy access to money induces people to borrow and spend but there are also other forces that influence their spending and consumption decisions. Marketing seems to be playing an increasingly crucial role in selling products. Capitalists spend a tremendous amount of money to promote and sell their products and, under monopoly capitalism, such trends have risen sharply. As Baran and Sweezy (1966) pointed out, under monopoly capitalism price competition is replaced by product differentiation and building a loyal consumer base; to achieve this, MNCs (multinational corporations) allocate huge amounts of money to advertising, marketing and developing slightly different products.

In fact, at present the level of advertising is much greater in the US than in other advanced economies. For example, at present total advertising expenditure in the US is far greater than the sum of the other advanced economies such as the UK, France, Germany, Holland, Italy, Spain and Japan. The constant bombardment of the US populace by marketing and advertising results in increased psychological and social pressure to buy more. It is well known that consumer demands are not exogenous but are rather shaped by the institutional process, and of particular influence is the advertising undertaken by big businesses. Moreover, under oligopolistic markets, intense rivalry and competition could lead towards high investment in adverts to develop new markets by devices such as advertising and product innovation and differentiation.

Such developments have strengthened the general notion of the "ideology of consumption" and the idea that progress is measured by the quantitative growth of consumption. Marx had already shown that it is the mode of production that determines the mode of consumption, and not the opposite, as is claimed, Marx called them vulgar economists. In fact, the huge potential associated with the application of science and technology can be of particular benefit the society and would enable the betterment of humanity. Under capitalism, such benefits are wasted by the necessity of their subordination to the logic of the unlimited pursuit of the accumulation of capital (Amin, 2009). 
Baran and Sweezy (1966) emphasised the idea that the new monopolies act differently; they set their prices simultaneously with the nature and volume of their outputs. So, this represents an end to "fair and open competition", which still remains important for mainstream economists. The end of price competition detaches the price system from its basis, the system of values, and in this way hides the referential framework which used to define capitalism's rationality from sight. Although we make considerable use of values to constitute autonomous realities, they become, in monopoly capitalism, the object of actual fabrications built through marketing and selling strategies.

Capitalism has been characterised by crises and instability in recent decades. Capitalism is in a period of global stagnation and instability. This is witnessed in the form of slow growth rates; the world economy has been growing at around $3,3 \%$ annually since 2008 , compared to the $4,5 \%$ the previous decade. Much of the world's growth between 2009 and 2017 has been due to growth in China and India, while the EU countries have barely contributed in this regard. China has become a significant global economic power in recent years, but still cannot adequately counter the effect of stagnation and lack of demand from major advanced economies. However, despite growth in a few regions, most countries and regions have witnessed deficiency in demand in the last decade.

The US still functions as a major source of demand for the global economy, thereby pulling along much of the rest of the world economy. However, since the early 1980s, the US current account deficit has risen to extremely high levels, which has generated demand from the rest of the world (Siddiqui and Dahle, 1989). This has no doubt benefited China, India and other emerging economies but did not benefit the remainder of the developing countries. Germany has followed a mercantilist approach which focusses on exports and due to this; the country has been running the largest surplus of any economy in the world since 2010. This policy has suppressed domestic wages and demand, and while productivity continued over the last decade, workers saw no increases in their wages. 
Since the global financial crisis of 2008, the world economy has not seen any consistent growth, but rather output recovery has been limited and fragile. Moreover, the recent employment increase in the US and Europe was temporary rather than long term, and did not reduce inequality or result in wage increases. The increased financialisation of the past three decades is responsible for the rising inequality in income distribution (Siddiqui, 2018a). Financial investments (largely speculation) continue to grow at a faster rate, one that is not commensurate with growth in GDP or in investment in real production. However, the rapid growth of financial investment requires, and also fuels, both household and sovereign debts; this is contrary to the government professing to pursue the goal of debt reduction. However, the financialised monopolies need growth in order to absorb their surplus capital (Fine, 2013).

Global capitalism and the economic system have been unable to deliver steady growth and prosperity for the people, while at the same time the persistent attack against trade unions and any application of fiscal policy has reduced workers' bargaining power. The long-term recovery under capitalism is disappearing, with stagnant aggregate demands and where new sources of demand such as financialisation and credit bubbles have provided no long-term solution. As Ghosh (2018, p. 194) argues, "This is the most evident globally in the overall deficiency of demand that characterises the world economy, despite a few pockets of relatively fast expansion. The underlined causes of this aggregated demand deficiency have existed for some time, but they were disguised by creditdriven expansions that were inherently unsustainable. The boom that preceded the crash of 2008 could occur because (particularly in the United States, but also in parts of Europe and some emerging markets) wage stagnation that would have led to stagnant demand was countered by financialisation that enabled consumption to increase faster than the real income of the majority of the workers... in the US and other advanced economies, the boom was based on speculative practises ... even during the boom, despite aggregate employment increases, most paid work became more fragile and less secure, in both developed and developing countries", 
The question arises as to whether capitalism could overcome and resolve conflict due to increased globalisation arising from the application of modern technology (Siddiqui, 2018a) which has led to capitalism becoming a more organised system than in the first decade of the 20th century. Rudolf Hilferding (1910) noted that the emergence of finance capital under monopolies could be seen as a new form of capitalism under which the separation between industrial capital and finance capital, which was a key characteristic of competitive capitalism, disappears. According to Hilferding, the new phase of the development of capitalism seems to be better organised and the possibility of capitalism is no longer subject to production anarchy and periodic economic crises. Under monopolies, they will be able to plan, produce and distribute, and therefore could eliminate overproduction crises. Karl Kautsky (1914) also pointed out that better organisation in production could eliminate interimperialist wars. However, he found that various challenges were unresolved between agriculture and industry. According to him, production and capital accumulation was much faster in industry than in agriculture, which could lead to increased investment in the former and result in tension between these two sectors. The theory of imperialism analyses the forms in which rivalry and economic competition become important features of modern capitalism. Some critics emphasise the fact that global capitalism is more integrated and thus evolved as peaceful international business and does not look towards national governments with regards to its interests (Robinson, 2004). They also claim that Lenin's (1964) theory of imperialism, especially inter-imperialist rivalries, is no longer relevant. Criticising such views, others argue that despite certain symmetries between the US and other advanced capitalist countries, a number of rivalries also exist. As David Harvey emphasises the potential conflict of: "increasingly fierce international competition as multiple dynamic centres of capital accumulation compete on the world stage in the face of strong currents of over accumulation. Since they cannot all succeed in the long run, either the weakest succumb and fall into serious crises of local devaluation or geopolitical struggles arise between regions. The latter can get converted via the territorial logic of power into confrontations between states in the form of trade wars and currency wars, with the ever-present danger of military confrontations (of the 
sort that gave us two world wars between capitalist powers in the twentieth century) lurking in the background" (cited in Ashman and Callinicos, 2006, p. 109-110).

Lenin (1964) observed that the tendency towards concentration and centralisation of capital is inherent to capitalism and does not eliminate competition but rather moves it to another level. This is because competition forces capitalists to further accumulation. In order for capitalists to survive, they have to continue to seek expansion. Lenin's contribution was to focus on the uneven development of capitalism, which redistributes power among the leading nations. This means the balance of power is constantly shifting, creating the occasion for new tensions and conflicts (Amin, 2009). This uneven development causes changes in the correlation of forces of the more advanced countries; as a result, it erodes the existing power relations in favour of a new pole of power, a country who has achieved greater economic dynamism, which could escalate into military conflict. In the 20th century, two world wars and the Great Depression proved that Hilferding and Kautsky were incorrect. Moreover, there was never any reduction in arms spending and in military conflicts in many parts of the world, even after the collapse of the Soviet Union and unipolar world. In the 20th century, two world wars and the Great Depression proved that Hilferding and Kautsky were incorrect. Moreover, there was never any reduction in arms spending and in military conflicts in many parts of the world, even after the collapse of the Soviet Union and unipolar world. For example, in the current unipolar world, where the US is essentially alone in its controlling position, arms expenditure still continues to rise. According to the SIPRI (Stockholm International Peace Research Institute), total world military spending was US\$1.78 trillion in 2016. The US alone spent more than $36 \%$ of this total in this same year (SIPRI, 2018). This clearly refutes Kautsky's prediction that the growth of monopolies will lead to a reduction in military spending. We find that the concept of imperialism still remains valid, allowing for the analysis of capitalism and exploitative relations.

Moreover, criticising Kautsky, Lenin defined the essential characteristics of the imperialist stage of capitalism, as characterised by the rise in the concentration of 
wealth and finance capital. It is also defined by its oppression of weak nations and their huge defence budgets (Siddiqui, 2017a). He also insisted on the political and economic centrality of the division of the world into oppressed and oppressor nations and "in its economic essence imperialism is monopoly capitalism" (Lenin, 1964, p. 266). He further argued that "The export of capital, one of the most essential economic bases of imperialism...sets the seal of parasitism on the whole country that lives by exploiting the labour of several overseas countries and colonies" (Lenin, 1964, p. 77). He further explained that monopolists were forced to export part of their capital in order to exploit the labour of overseas workers because they had accumulated enormous wealth that had reached such high proportions. For instance, the export of capital in the last three decades or so has provided transnational corporations with ways to capture the surplus value extracted from workers in low wage countries without having to export their capital into those countries (Patnaik and Patnaik, 2016). Lenin (1964) characterised imperialism as a specific stage of the development of capitalism, i.e., monopoly capitalism, and is not merely associated with extra territorial expansion and increased political and economic control. He found capitalism in the last quarter of the 19th century, with its inherent tendency towards the process of capital accumulation where concentrations and centralisation becomes crucial, and competitions were not eliminated among different capital formations. The development of monopolies did not lead to the elimination of crises but it did supress them. Lenin further emphasised the fact that anarchy and contradictions were far from being resolved under monopoly capitalism, and that this could escalate. As Lenin argues, "The statement that cartels can abolish crises is a fable spread by bourgeois economists who at all costs desire to place capitalism in a favourable light. On the contrary, monopoly which is created in certain branches of industry increases and intensifies the anarchy inherent in the system of capitalist production as a whole" (Lenin, 1964, p. 70).

Robinson (2004) argued that modern capitalism has transformed itself extensively due to the rise of transnational capital and the integration of countries into regional cooperation and the new global financial system where, despite the existence of national capital, a new transnational capitalist class has emerged and 
transnational capital has increased its domination globally. Moreover, with recent globalisation, competition occurs among global corporations, rather than within countries. "As national states are captured by transnational capitalist forces, they tend to serve the interests of global over local accumulation process" (Robinson, 2004, p. 17). In fact, imperialism has the intrinsic need to export capital in order to reduce costs and seek higher profits. Capital exports also lead to increased competition among countries. International corporations can operate in several regions, and indeed globally, but still they need to remain linked to their home country from where they can receive legal protection and support.

While researchers such as Harvey (2004) and Callinicos (2009) have criticised the conclusion that capitalism could create stability and ultimately put an end to inter-imperialist rivalries. Competition between capitals is crucial in the accumulation process. The capitalists require a degree of support from the particular state with which they are associated. For instance, in the current global negotiations on trade liberalisation under the WTO, the capitalist would like their interests to be protected; furthermore, the expansion of capital overseas depends on their ability to maintain power both internally and externally. The state's principal interest would be to prompt the process of capital accumulation and pursue policies which facilitate this process (Patnaik and Patnaik, 2016).

Imperialism is today taking new forms. Nevertheless, the international expropriation of any surplus from poorer countries has not ceased, and indeed is being carried out by multinational corporations based largely in the rich countries and which are able to exploit the global labour arbitrage, leveraging their entrenched positions in the wealthiest countries and the monopolies of finance and technology. As Amin argues, "Accumulation, which is synonymous with pauperization, provides the objective framework of the struggles against capitalism. But accumulation expresses itself globally mainly by the growing contrast between the affluence of the societies in the centre of the world system that benefit from imperialist "rent" and the misery of the societies in the dominated peripheries" (Amin, 2009). According to him, the rise of financial capital, imperialism can be defined as: "in its briefest possible definition" as the 
"monopoly stage of capitalism". He wrote about hegemonic transitions to gain control of the world. He developed a multidimensional theory of imperialism, focussing simultaneously on factors such as control of the world's strategic raw materials, export of capital, and expropriation of surplus, international finance, geopolitical struggle and war.

Rosa Luxemburg's (1951) preposition that capitalist accumulation requires an external stimulus for its realisation crisis to be overcome and the stimulus was found in the natural economy of non-capitalist countries. It also includes ensuring the supply of raw materials without which there would have been no manufacturing whatsoever no matter how small its share was in the gross value of manufacturing output. At present too, all these requirements persist in the era of globalisation. Samir Amin (2015) argues that since 2006, capitalism has entered a new phase of the monopoly stage of capitalism, namely monopoly-finance capital, or global monopoly finance capital, in which the main countervailing factor to stagnation in the core of the system is financialisation, which necessarily results in financial bubbles that eventually burst.

Neoliberalism as a policy measure gives more power to those institutions which can further increase their control over surplus. Mainstream economists also suggest that the market is the only efficient way to carry out economic activity. Given the limits on consumption imposed by the unequal income distribution, any effort to expand productive capacity would thereby compound the problem of excess capacity, inhibiting investment.

\section{The US Economy and Global Imbalance}

The US current account deficit is due to the overspending in the US, which is the ultimate cause of global imbalances, though others blame 'policy exchange rates' adopted by those countries running trade surpluses intended to keep the appreciation of their currencies under control (McBride, 2017; Wolf, 2008a). If exchange rates were flexible, then in the surplus countries' currency would appreciate against the US dollar until the imbalances are removed (Siddiqui, 
2019). Such arguments hold countries with surplus directly responsible for the problem of US deficits. The US dollar still accounts for two-thirds of all foreign exchange reserves and the ability of the United States to run large current account deficits has turned out to be a calamity (De Cecco, 2012).

Bernanke's 'saving-glut' theory argues that US overspending has caused a US trade deficit due to which money is flowing into the US market from other countries through its capital account. This leads to the credit expansion and lower interest rate which makes it attractive for US consumers to overspend, as a result of which US household consumption increases global demands. Here, it should be emphasised that the US trade deficit gives rise to excessive global savings and this needs to be addressed first, otherwise reducing global imbalances by raising US savings would lead to a global slump and recession. Bernanke also argued that high saving rates in surplus countries, especially in East Asian countries, are due to historical, cultural and demographic factors (Glyn, 2005), while others pointed out that the 1997 East Asian crisis was an important reason for such behaviour (Wolf, 2018b). Others emphasise the fact that excessive global savings are due to structural causes and cannot be corrected simply by these measures (Wade, 2017).

Flexible exchange rates and free capital movement have been unable to keep the world economy stable (Siddiqui, 2017b). The emerging economies have built up massive foreign exchange reserves, mainly to ensure the means to defend themselves from panic capital withdrawals, as was witnessed during the 1997 East Asian crisis and again after the 2008 financial crisis. Such sudden withdrawal of capital proved to be costly in terms of their investment, economic growth and overall development. This uncertainty also adds to global imbalances (Fine, 2013).

The continuous rise in foreign reserves in foreign countries leads to an increase in demand for US financial assets. It is tied to the ever-rising inflow of funds into the US financial system from abroad and encourages asset prices bubbles, while the excessive reserve accumulation overseas is due to developing economies 
trying to self-insure against the possible speculative currency attacks. They are cautious, and are guarding against the possibility of sudden investment collapse or capital flight or domestic currency appreciation, as these could adversely affect export competitiveness and economic stability (Fine, 2013; Willett et al, 2012).

\section{Figure 1: Real GDP Forecast for Selected Economies, Total, Annual growth rate (\%), $2009-2020$}

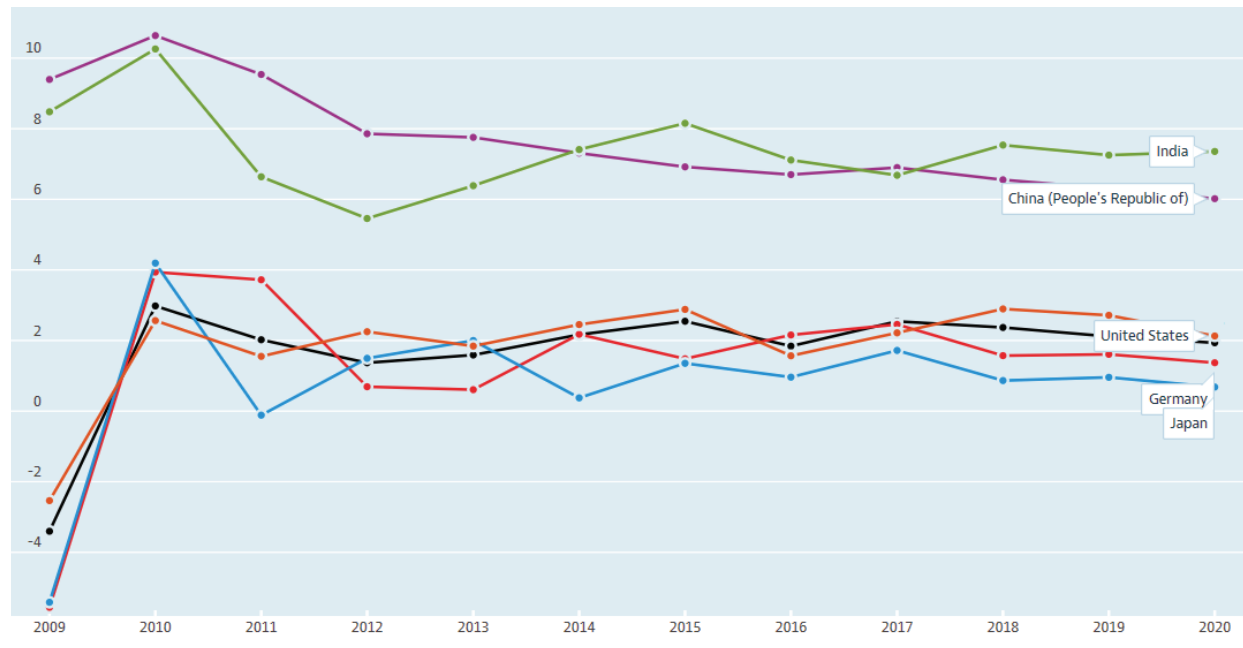

Source: OECD, Paris. (Accessed on 22 December 2018). Retrieved from https://data.oecd.org/gdp/real-gdp-forecast.htm

The US economic growth is low by historical standards, with only a 2,3\% increase in GDP in 2017. In 2016, US economic growth was 1,5\%, while EU growth was $2 \%$ and China's was $6,7 \%$. The EU's average growth rate was $2,5 \%$, and China's $6,9 \%$ (See Figure 1). There seems to be a strong correlation between US output growth and the percentage of net fixed investment in the US, meaning that in the long term it is not possible for the US economy to accelerate without an increase in net fixed investment. For example, in 1966, during the long-term boom, the US net fixed investment was $11,3 \%$ of its GDP, but in 1978 US net fixed investment was $10,5 \%$ of US GDP. In 1984, US net fixed investment decreased to $9,2 \%$ of US GDP. In 1999, it was $8,3 \%$ of GDP, in $2006,7,9 \%$ of GDP, in $2017,4,2 \%$, and in $2018,5,1 \%$. There was a small recovery in US net fixed investment in the last year, but still the US fixed capital formation remains far below that of the post-war period and, indeed, below the pre-financial crisis of 2008 levels. 
Trump's tax cuts, for US corporations and the rich, which are not matched by government spending reductions, will sharply increase the US budget deficit. All else being equal, this policy will reduce US domestic savings and therefore reduce the US domestic capacity to finance investment. This will increase the federal deficit and push up bond yields to attract foreign buyers. Moreover, the US share of the global domestic product is estimated to be less than $20 \%$, while US-based companies control about half of the world's wealth. Of course, these facts show us a very complex picture of the contemporary world.

The current crisis in the US is a product of the structural crisis of capital in our time, evidenced by stagnation, financialisation, monopolisation, and environmental crisis. The structural crisis has been building for decades, where growth has not been leading to job creation and job security. All these developments have brought crises of the liberal-democratic state. Neoliberalism, which has reached its limits, is further raising inequalities within the advanced economies, and thus giving rise to extremist tendencies which threaten liberal democracy itself. In the US, these conditions are more visible with the decline of US hegemony in the world economy (Kotz, 2018; Harvey, 2005).

The relative decline of the US as a global economic power is clear, and can be seen in the associated economic statistics. The US is definitely in a less powerful position than in the past decade with respect to production and productivity. However, it is still successfully siphoning off much of the economic surplus created in the developing countries with the help of large US-based corporations and the US hegemony over global finance. With respect to US financial dominance, the key issue becomes that of the continuation of the dollar as the hegemonic currency, which is certainly facing challenges at present with the rise of China. However, the US still has by far the largest defence spending in the world. The country has maintained supremacy mainly through the role played by its defence sector in technological advancement. This will be difficult for the US to maintain due to the slowdown of its economic position in the world. However, this still does not in any suggest a smooth transition to a multipolar world. Periods of hegemonic instability in the capitalist world economy in the 
past have given rise to two world wars and the conditions that allowed for the rise of fascism in the last century.

The current recovery in the US is fragile, and is a product of the expansion of the global financial system of the previous decades and of expansion in the financial sector. As capital develops, money cannot find a ready outlet and moves into interest-bearing capital. In recent decades, interest-bearing capital has expanded 'magically' as it receives a huge amount of interest payments (Itoh and Lapavitsas, 1999). During the 19th century, Karl Marx had already commented that the growth of finances beyond a certain limit could deepen a crisis. He noted that: "Through the banking system, the distribution of capital is removed from the hands of the private capitalists and usurers and becomes a special business, a social function. Banking and credit, however, thereby also became the most powerful means for driving capitalist production beyond its own barriers and one of the most effective vehicles for crises and swindling" (Marx, 1991, p. 742).

The expansion of credit generally helped both to conceal and to defer capitalism's problems in the period from the early 1980 s as part of a system sometimes dubbed "privatised Keynesianism", but only at the expense of creating a grotesquely oversized financial system that would ultimately explode into crisis. The fact that the long depression began in the field of finance led many commentators to identify it simply as a financial crisis (Norfield, 2016). On debts, Marx also noted: "The chain of payment obligations at specific dates is broken in a hundred places, and this is still further intensified by an accompanying breakdown of the credit system... All this therefore leads to violent and acute crises, sudden forcible devaluations, an actual stagnation and disruption in the reproduction process, and hence to an actual decline in reproduction" (Marx, 1991, p. 363). In fact, shares traded on the stock market differ from bonds, as they represent ownership of a company and also pay dividends to shareholders, but can also be an asset-generating income. Such types of income are what Marx termed "fictitious capital". He explained that such an income stream highly resembles of earnings from interest and, according to him, the fictitious capital trades according to its own laws of motion. This could be used for speculation and could create bubbles 
as investors expecting higher profits further increases the prices of these assets based on future income expectations.

Financialisation has been described in terms of the dominance of finance over industry. It does not mean that finance is controlling and dictating the industrial sector. Various studies have pointed out that in the advanced economies; corporations are increasingly less reliant upon the financial sector to fund their operations (Norfield, 2016). Moreover, in the US, for instance, non-financial corporations are increasingly moving into financialisation, i.e., derived their profits from their own financial, rather than productive, activities. As Martin Wolf has described it, "The US itself looks almost like a giant hedge fund. The profits of financial companies jumped from below 5 percent of total corporate profits, after tax, in 1982 to 41 per cent in 2007" (Wolf, 2008b).

Soon after the 2008 financial crisis, the Federal Reserve, the Bank of England and the European Central Bank launched quantitative easing programmes or, in the case of the Bank of Japan, expanded an existing programme. Quantitative easing involves central banks electronically creating money and using it to purchase assets from banks and other financial institutions, in particular acquiring government bonds (Itoh and Lapavitsas, 1999). Doing so has two effects. First, it floods the banking system with liquidity, supposedly encouraging lending. Second, it drives up the price of bonds. Bonds pay a fixed income at regular intervals, so if they increase in price, their "yield", the return on the investment relative to the price, tends to fall. Lower yields mean lower borrowing costs (Fine, 2013).

Despite the persistence of high levels of sovereign debts in the US, no country is currently willing to challenge the dollar as the representative international currency. As Patnaik noted, any alternative to the dollar as an international currency in the current set-up will require a country to challenge the status quo. He argued that a fall in value in terms of oil could lead to the decline, and finally replacement, of the dollar. At present, there is no attempt nor, it seems, any interest among major dollar holders or among top major economies to seek such an alternative. Currently, the major creditors to the US, namely China, Japan, 
Germany and the oil exporting Middle East countries, rely heavily on the US markets to prop up their own domestic demand and economy. In the US, real wages have fallen since 2008 but domestic demand has continued to grow thanks to household borrowing, and domestic and international sources. Also, external factors have contributed to the decline in manufacturing prices by moving production overseas and thus raising profits (Patnaik, 2009).

It seems that global imbalances play two crucial roles as they highlight the past mistakes in monetary and financial regulation and also provide an opportunity to reorganise capitalism. The neoliberal model pursued for nearly four decades but failed to deliver, yet the mainstream view is that 'we must have more globalization'. A major crisis could be a chance to change economic policy and could also lead to the redistribution of wealth and power and, as a result, benefit certain classes and sectors while restricting others. For example, decolonisation became possible due to two world wars weakening the European power to brutally control and exploit their colonies (Siddiqui, 2017a), and negotiations between employers and employees became the norm with trade unions playing a much greater role in wage negotiations. The Anglo-American variety of capitalism was thoroughly discredited, and US global power had weakened both in the areas of the economy and defence. The model of neoliberal capitalism has been presented by the WTO, IMF and World Bank as the only alternative, which is based on the efficiency of the markets and the belief that the pursuit of self-interest also promotes the public interest (World Bank, 2017).

However, the deepening crisis in the 1970s, with rising inflation and unemployment, questioned this strategy. In the early 1980s, the US assigned an increased role to market forces through privatization and deregulation. Trade unions and the performance of the public sector were attacked. Capital liberalisation and deregulation of the financial sector led to a rapid expansion in this sector, otherwise known as financialisation (Fine, 2013).

Since the 1980 s, the policy adopted is referred to as 'neoliberal capitalism'. During the 1990s and 2000s, economic expansion was associated with the rapid 
rise in real estate prices. However, by 2006 these prices had begun to stagnate and ultimately reached a plateau. Soon after 2007, in the US the housing markets saw a deep fall in prices that was quickly followed by the sub-prime financial crisis and the economic recession. The deflating real estate bubble brought down the market value of the new derivative securities, which constituted a large fraction of the assets of the banks that had accumulated a huge amount of debt (Kotz, 2018).

However, as the crisis deepened in the 1990s, neoliberal capitalism was adopted within the major capitalist countries. This led to the loss of the gains made in previous decades, especially in income distribution. For instance, in the US the income share of the top income group (1\%) declined from $29 \%$ in 1929 to $8 \%$ in 1970 and stayed the same until 1979, while the lower and middle income groups experienced greater increases in their incomes. By contrast, the neoliberal regime pursued since the 1980s reversed the redistributive policy. For instance, in the US, the incomes share of the top $1 \%$ in the US rose very sharply to $23 \%$ by 2008 (Wade, 2009).

In fact, the rate of accumulation responds to the rate of profits in the economy which happens when profit rates increase, meaning higher expected returns from expanding capital stocks. Profit rates fell during the 2008 crisis, but after 2013 rose again, but have slightly fallen again since 2014. The recovery of 2012-14 was associated with debt-financed consumer spending, which is not sustainable in the long term. The 2014 recovery took place when consumer spending accelerated while investment in the economy slowed, and government spending also declined in real terms over the same period, resulting in an adverse impact on output growth. During this period, US imports grew faster than exports, and therefore the biggest factor to have contributed to GDP growth in recent years in the US has come from household consumer spending, which has contributed $81 \%$ of its increase in the 2014-17 period while investment slowed to 2,1\%, contributing to only $16 \%$ of GDP growth over the same timeframe (Kotz, 2018). As Kotz argues that "The current structural crisis has taken the form of stubborn stagnation despite unprecedented monetary stimulus, with slow economic growth, a low rate of capital accumulation, stagnating real wages and worsening economic insecurity for working people- conditions that have helped to produce new 
political polarization" (Kotz, 2018, p. 30). Similarly, Glyn (2005, p. 10) also notes: "The consumer boom of the late 1990s had sucked in large quantities of consumer good, from China in particular, with the volume of imports into the USA rising by 75 per cent between 1995 and 2000. Imports took 26 per cent of the US market for manufactures in 2000, including 80 per cent for leather and shoes, 57 per cent for apparel, 51 per cent for computers and electronic equipment, and 33 per cent for cars and a wide swathe of machinery".

The US has witnessed a decade of slow growth, low investment, and low productivity, all of which has been further marked by increased public debts. As Wade (2009, p. 545) notes: "The US government's privilege of paying its debts in its own currency rather than in someone else's softens the pressure on it to cut its deficits and get its banks working. The US central bank can just print even more than it has been doing, reducing the pressures for adjustment and raising the potential for a later inflationary surge. The outcome could be stagflation in the USA and damage to countries that hold dollar assets in their foreign exchange reserves". All of these factors have contributed towards higher levels of current account deficits. Further, by raising import tariffs, the US has violated the WTO's multilateral trade rules, which ironically were negotiated earlier under the US leadership.

Figure 2: Current account balance - total, \% of GDP, 1990-2017

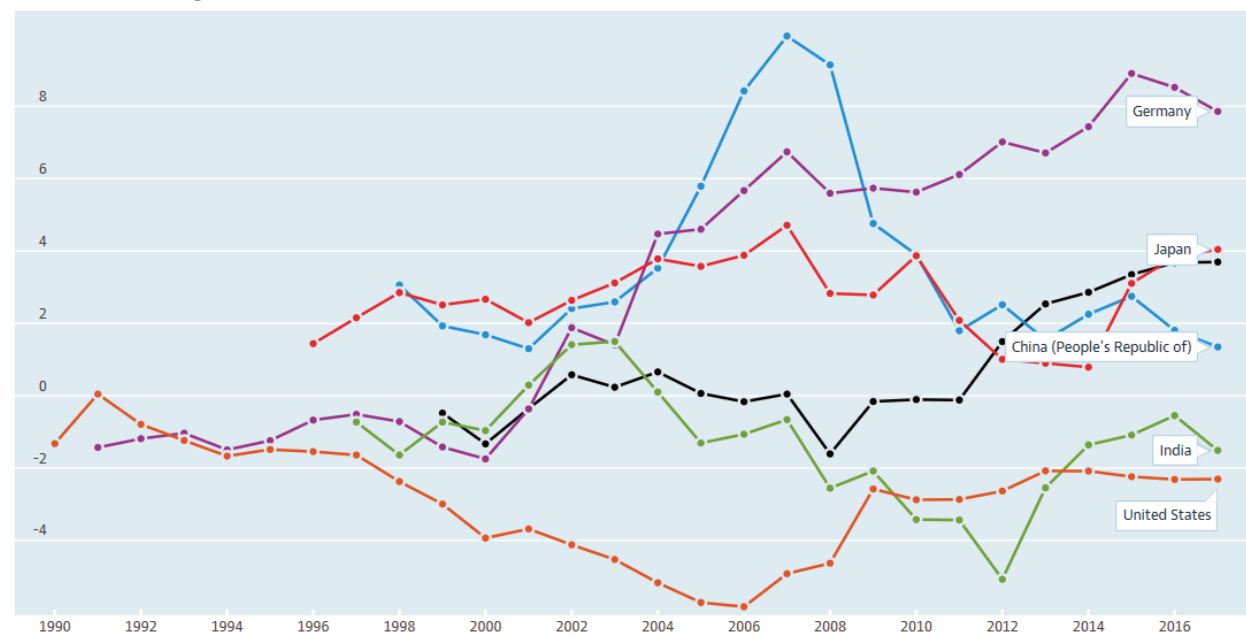

Source: OECD. (Accessed on 4 January 2019). Retrieved from https://data.oecd.org/trade/current-account-balance.htm Note: Euro area 19 countries shown in black colour. 
The question arises as to whether the United States' protectionism is justified. Therefore, in order to assess this, we will attempt to take a somewhat long-term view regarding the external payments situation of the US. Figure 2 provides a summary of the current account balance of selected economies.

We need also to analyse the US trade in goods and services and its current account situation on the basis of available statistics. The data shows the external sector payments of the US from 1970 to 2017 (See Figure 3). Apart from few exceptions, most of the time its current account was negative in goods. However, the late 1980 s service sector gained a surplus and is steadily rising. Despite these changes, the rise in service export was unable to fill the gap created by the general trade imbalance in goods. Moreover, since 2014, service export has stagnated, which has thus become a real problem for the US and its trade deficit kept on rising, and has grown remarkably over the last two decades. This was coincident with the period when China joined WTO, all of which appears to have given the US the excuse to blame China for raising its trade deficits.

Figure 3: Trends in United States' External Payments (\$ billion)

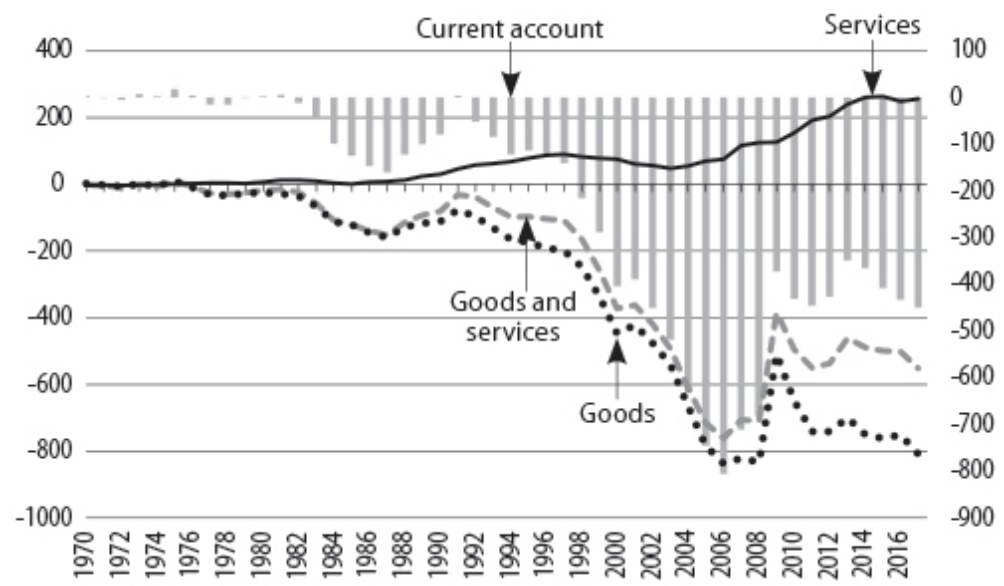

Source: International Monetary Fund (IMF), 2018. 
Figure 4: United States - China Trade in Goods (1985-2017)

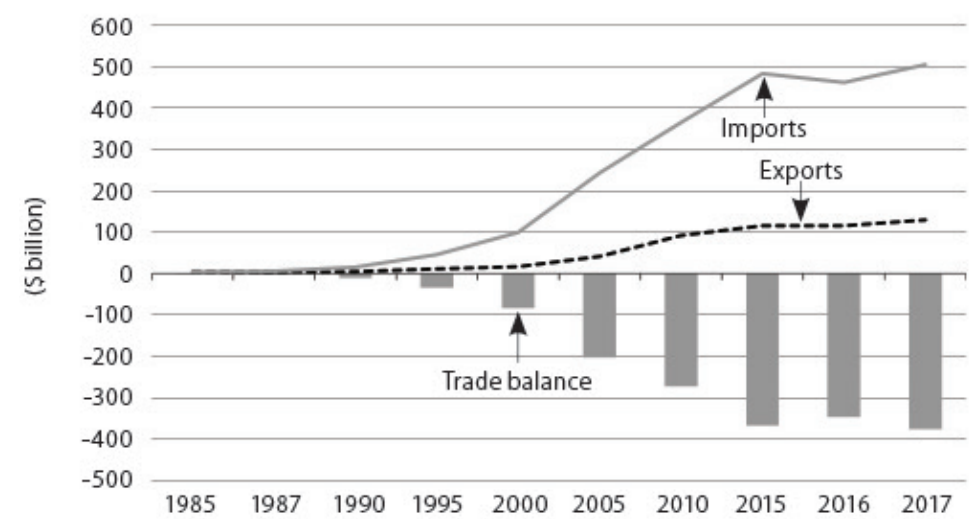

Source: US Census Bureau, US Department of Commerce. 2018.

Figure 4, which shows the trade in goods between the US and China, indicates that the US had trade deficits in goods with China since the early 1990s, which has grown up sharply. For example, the deficit was only US $\$ 10$ bn in 1990, but by 2000 had reached US\$100 bn; by 2005 it had risen further to US\$200 bn, by 2012 it rose to US\$315 bn, and by 2017 it had reached US\$376 bn. The sharpest rise was since 2001, which also coincided with China joining the WTO. For example, China's exports to the US increased from US\$125 bn to US\$505 bn, while US exports to China rose from merely US\$19 bn to about US\$130 bn for the same period (World Bank, 2017).

Figure 5: United States' Trade Deficit with all Trading Partners

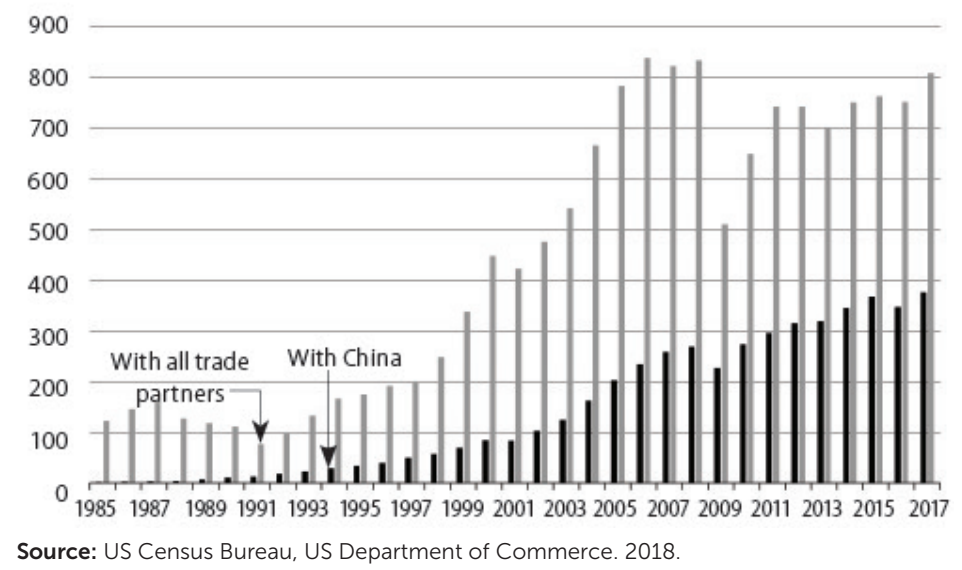


The question arises as to the extent to which China is responsible for the US's rising trade deficit (McBride, 2017). To answer this, we need to examine the US trade performance with the other major trading partners. Figure 5 indicates that China is an important trading partner for the US, but that China still has less than half of the US's overall trade deficits. For example, according to the statistics, in 2017 the US's trade deficit with China was US\$375 bn, however, its overall trade deficit was US\$775 billion. This means that even if the US were to eliminate its trade deficit with China, its trade imbalance problems would still exist.

In fact, US trade imbalances are largely self-inflicted (Siddiqui, 2018b). The US needs to address factors within its economy rather than blaming others, especially China. Trade deficits (i.e., imports more than export), reflects the savinginvestment gap in terms of national income, which is associated with low levels of domestic saving rates (Siddiqui, 2016). Most economists and policy makers have barely touched on this important issue, namely that consumption has risen while saving rates have declined, or otherwise remained low. For example, the US domestic savings rate was never higher than $24 \%$ in the 1950-60s, but for the last two decades it has steadily declined and is now below 17\% (McBride, 2017). Personal savings as a proportion of disposable income in the US have fallen from an average of $10 \%$ between 1975 and 1985 to around 5\% by the 1995 and further fell to merely $0,7 \%$ in 2010 . While at the same time the debt of the US households has risen sharply in recent years (Siddiqui, 2018b).

There are serious structural weaknesses in the US economy which needs to be addressed. Blaming its trading partners might help the US in the short term, but will certainly not be effective in the long term. Trump, rather than addressing structural crisis, has taken the initiative to cut corporation tax and increase tariffs, which seems to be short term relief that will as the same time increase imports. In 2002, during the Bush administration, higher tariffs were imposed on imported steel and aluminium, but rather than helping, this adversely affected the automotive and construction industries, which are amongst the largest employers in the US. 
To compare the current US situation with Britain soon after the First World War, Britain had sold most of its foreign assets and tried to bring back the Gold Standard without sufficient gold reserves and with a weak current account, which ended in drastic failure. But there are crucial differences between 1920s Britain and the current US position. The US is still the largest economy in the world and severed the dollar link to gold in 1971, since when the dollar could only be converted into other national currencies. Despite the US current account deficit continuing since 1982, none of the surplus countries have attempted to sell the dollar on a large scale in order to get rid of global imbalances (Wien, 2010). The US decided to have a strong dollar, as did Britain in the $19^{\text {th }}$ century, in order to reduce inflation and attract foreign assets to boost country's financial markets. Due to relatively higher wages and strict environmental regulations, the companies decided to reallocate in the developing countries, especially labour-intensive industries where wages and taxes are low. As a result, manufactured imported goods replaced domestic produced ones.

\section{Rapid Growth of the Chinese Economy}

China's market reform in 1978, and an alliance with global capital, made China the world hub for the global labour arbitrage of multinational corporations, which shifted their production to China in particular in order to exploit low labour costs to achieve economies of scale. In fact, the Chinese government has used its share of the proceeds to promote urban development and to provide infrastructural development that facilitated the ability of MNCs to do business there and enhance their profit. China's huge migrant labour population has provided a reserve army of labour that has kept wages low.

A very rapid capital accumulation has led to a spectacular rise in in China's share of world GDP, which nearly tripled from $5 \%$ to $14 \%$ in less than twenty-five years. In terms of per capita incomes, in the last two decades China has doubled the ratio of per capita income compared to the US, but is still far behind where Singapore, Taiwan and South Korea were before three decades of rapid economic growth in the late 1960s. 


\section{Figure 6: Government Reserves - Total, SDR millions, and 1991 - 2014}

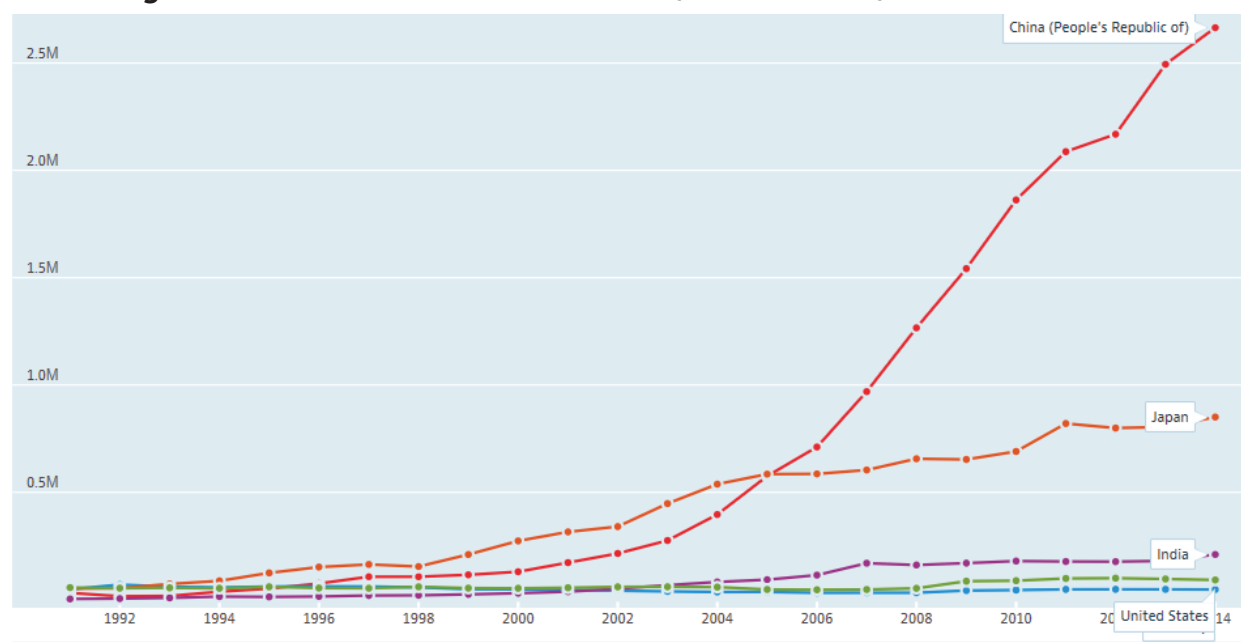

Source: (Accessed on 6 January 2019). Retrieved from https://data.oecd.org/gga/government-reserves.htm Notes: US is shown in green and Germany in blue colours.

In China's case increases in investment seem to be most dynamic element in the expansion of aggregate demand. As Angus Maddison (1998) calculated, the Chinese investment share to GDP was nearly one-third between 1978 and 1994. This figure was very close to that reached by Japan and South Korea in their early phases of industrialisation. He noted that a large proportion of China's investments went to machinery and equipment areas, which are often the main engine of rapid growth; its ratio to GDP was about 20\%, which was, according to Maddison, 6 percentage points less than in Japan and South Korea during their very high growth periods, and 3-4 percentage points more than France and Germany during their rapid growth periods.

China's share of world trade has increased enormously since the early 1980s and its government reserves have risen sharply in the last two decades (See Figure 6). Its real GDP rose by over thirty-fold between 1980 and 2015 . This is also known as the Chinese growth miracle, which was based on very high rates of investment, directed credit, state control, export markets and foreign capital. However, since 2008, Chinese growth has been heavily based on internal debt which the country is now rebalancing through lower growth and investment rates. This has also led to a sharp reduction in Chinese imports. 
China is largely facilitating the final assembly stages of global production networks of vertically integrated high-tech industries. To explore the magnitude and patterns of trade arising from cross-border production networks, it is necessary to separate parts and components from final assembled products traded within global production networks. The US trade war, if broadened, will adversely affect US corporations as well (Siddiqui, 2018b).

Figure 7: China's Manufacturing Exports, 1992-2015 (US\$ billion)

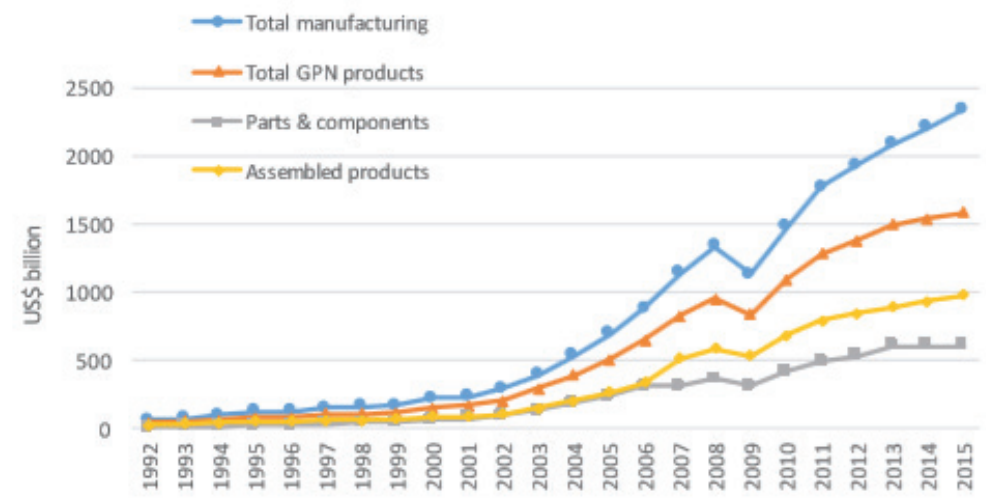

Source: Data retrieved from UN Comtrade Database. Retrieved from comtrade.un.org/

Exports of global production network (PN) exports from China rose from US\$47 bn in 1993 to US\$1.3 trillion in 2015, where these products accounted for more than $70 \%$ of China's total manufacturing exports as indicated in Figure 7. This pattern shows China's dominant role as an assembly centre within global production networks. In 2015, China accounted for $27 \%$ of the total global network product exports worldwide, compared with an $18 \%$ share in total world manufacturing exports. This means the shares of both final assembly and components were notably higher than the aggregate global export share.

In contrast to this, the US contributes only $26 \%$ to global growth. Despite the slowdown in growth rates in China, the country still occupies a very significant position in world trade. In 2013, China overtook the US to become the world's largest merchandise trader and, in 2015, accounted for more than $13 \%$ of the world merchandise export, while the US share was only $9 \%$ and $11 \%$ of global 
imports, while the US share in global imports was $13 \%$. In 2015, China also emerged as the largest trading partner for more than 43 countries, compared the US which is the largest trading partner for only 35 countries (Ghosh, 2018).

Moreover, China is challenging the advanced economies monopoly in robotics and 3D printing. The Chinese government has undertaken a huge investment drive in aviation engines, electronic chips and set a target to become the largest investor in R\&D in the world. Despite all these changes, the US wants to maintain the US dollar as the de facto global currency, even at the expense of huge trade deficits (Siddiqui, 2019).

\section{Conclusion}

Current account imbalances have left US capitalism more vulnerable and there seems to be few possibilities of macroeconomic coordination in policies that could generate increased demand. The use of a fiscal policy is seen by monetarists as a means to generate inflationary pressure. However, the deregulated financial system would encourage speculative activities and instability. Post-financial crisis reform has been inadequate, though limited, regulation in the financial sector.

The history of capitalism is characterized by phases of growth and stagnation which were not produced by the monetary system. In fact, it is inherent to nature of capitalism to create relative overproduction and show a tendency towards stagnation, and this could be caused by stagnation. Capitalist expansion does not imply that growth leads to full employment or job security or equality in the distribution of incomes. In fact, the economic growth is largely aimed at corporations searching for higher profits. This may lead to expansion of employment under some conditions, or its contraction under others.

Moreover, the crisis under monopoly capitalism is a crisis of the presence of excessive capacity. This excessive capacity could lead to lowering production activities and rising unemployment. Given the ever-widening inequality of income and distribution, the money cannot be invested to produce productivity- 
enhancing capital because doing so could only compound the problem of excess capacity further.

This study concludes that the trade deficits on the current scale cannot continue forever. Although such imbalances occurred in the $19^{\text {th }}$ century in Britain when the country had colonies, but in the $21^{\text {st }}$ century the US has no such colonies and under the current situation it is less possible. Closing the trade deficit will require a more equal distribution of world spending, meaning a fall in US spending and a rise in spending from the rest of the world. Policy measures should be taken to increase state spending rather than rely on debt-fuelled private consumption to resolve inadequate aggregate demands. More investment in skills and education will increase labour productivity which will have a positive impact on profit rates, as happened during the post-war period under regulated capitalism, while rising wages, consumer and government spending would result in higher investment and capacity utilisation.

In recent years China's GDP has increased sharply and also its trade. The Chinese economy is now the world's second-largest economy. It is also the secondlargest global trader and currently holds the largest amount of foreign exchange reserves. In recent years, the Chinese economy accounts for more than one-fifth of incremental demand worldwide. Moreover, a number of fast-growing developing economies have boosted global demand. China's share of world trade has increased enormously since the early 1980s and its government reserves have risen sharply in the last two decades. Its real GDP rose by over thirty-fold between 1980 and 2015. In 2015, China accounted for more than 13\% of the world merchandise export, while the US share was only $9 \%$ and $11 \%$ of global imports, while the US share in global imports was $13 \%$. In 2015, China also emerged as the largest trading partner for more than 43 countries, compared the US which is the largest trading partner for only 35 countries.

Finally, in order to achieve a balanced economy and more equal distribution of incomes and wealth, the US should raise tax on the rich and big corporations. It should also expand its industrial base and increase exports. However, this cannot 
be achieved simply by depreciating the value of the US dollar, but rather with a new industrial policy with a more active state intervention aimed at increasing investment in the economy, including R\&D and infrastructure.

Acknowledgement: The author would like to thank John Smith and Phil Armstrong for helpful suggestions on earlier drafts and also reviewers of this journal for the comments, which definitely has improved the paper.

Grant Support: The author received no financial support for this work.

\section{References}

Amin, S. (2009). "Seize the Crisis!" Monthly Review, December. Retrieved from https://monthlyreview. org/2009/12/01/seize-the-crisis/

Amin, S. (2015). "Contemporary Imperialism", Monthly Review, July. Retrieved from https:// monthlyreview.org/2015/07/01/contemporary-imperialism/

Ashman, S., \& A. Callinicos. (2006). Capital Accumulation and the State System: Assessing David Harvey's New Imperialism. Historical Materialism, 14(4): 107-131.

Baran, P., \& P. Sweezy. (1966). Monopoly Capital. New York City, New York: Monthly Review Press.

Bullard, S., Silvia J. E., \& Iqbal, A. (2017). "Can We Estimate the Cost of a Recession?" American Economic Association Conference. (Accessed on 6 June 2018). Retrieved from www.aeaweb. org/conference/2017/preliminary/paper/bzQ4bKGK

Callinicos, A. (2009). Imperialism and Global Political Economy, Cambridge-Massachusetts: Polity Press.

De Cecco, M. (2012). Global Imbalances: Past, Present, and Future. Contribution to Political Economy, 31, 29-50.

Fine, B. (2013). Financialization from a Marxist Perspective. International Journal of Political Economy, 42(4), 47-66.

Ghosh, J. (2018). "Global Instability and the Development project: Is the Twenty-first Century Different?" European Journal of Economics and Economic Policies: Intervention, 15(2), 193-207.

Glyn, A. (2005). Imbalances of the Global Economy. New Left Review, 34, 5-37.

Harvey, D. (2004). The New Imperialism, Oxford, UK: Oxford University Press.

Harvey, D. (2005). A Brief History of Neoliberalism, Oxford, UK: Oxford University Press.

Hilferding, R. (2010). [1910]. Finance Capital, London, UK: Routledge \& Kegan Paul.

Itoh, M., \& Lapavitsas C. (1999) Political Economy of Money and Finance, London, UK: Macmillan.

Kautsky, K. [1914]. Ultra-imperialism. (Accessed on 22 December 2018). Retrieved from https:// www.marxists.org/archive/kautsky/1914/09/ultra-imp.htm 
Keynes, J. M. (1973). [1936]. The General Theory of Employment, Interest and Money, London, UK: McMillan/Palgrave.

Keynes, J. M. (1980). The Collected Writings of John Maynard Keynes, Volume XXV: Activities 19401944: Shaping the Post-War Economy, London, UK: Macmillan.

Kotz, D. (2018). "End of Neoliberal Era?" New Left Review, 113, 29-55, September-October.

Lenin, V. I. (1964). "Imperialism, the Highest Stage of Capitalism," in Collected Works, vol. 22 Moscow, Russia: Progress Publishers, 1964; originally published [1916].

Luxemburg, R. (1951). [1913]. The Accumulation of Capital, London, UK: Routledge and Kegan Paul. Maddison, A. (1998). Chinese Economic Performance in the Long Run, Paris, France: OECD.

Marx, K. (1991). Capital, Volume 3, London, UK: Penguin.

McBride, J. (2017). "The US Trade Deficit: How Much Does It Matter?," Council on Foreign Relations, 17 October. Retrieved from https://www.cfr.org/backgrounder/us-trade-deficit-how-much-does-it Norfield, T. (2016). The City: London and the Global Power of Finance, London, UK: Verso.

Patnaik, P. (2009). The Value of Money, New York City, New York: Columbia University Press.

Patnaik, U., \& P. Patnaik. (2016). A Theory of Imperialism, New Delhi, India: Tulika Books.

Robinson, W. (2004). The Theory of Global Capitalism: Production, Class and IState in the Transnational World, Baltimore, Maryland: John Hopkins University Press.

Siddiqui, K., \& T. Dahle. (1989). "World Economy Heading Towards Recession", Bergens Tidende, (in Norwegian) 3rd July, Bergen.

Siddiqui, K. (2016). "International trade, WTO and economic development". World Review of Political Economy, 7(4), 424-450.

Siddiqui, K. (2017a). "The Bolshevik Revolution and the Collapse of the Colonial System in India", International Critical Thought, 7(3), 418-437. Routledge Taylor \& Francis. doi.org/10.1080/2159 8282.2017.1355743.

Siddiqui, K. (2017b). "Financialization and Economic Policy: The Issues of Capital Control in the Developing Countries", World Review of Political Economy, 8(4), 564-589, winter, Pluto Journals.

Siddiqui, K. (2018a). "Capitalism, Globalisation and Inequality", World Financial Review, November/ December, pp. 72-77. ISSN 1756-3763. Retrieved from http://www.worldfinancialreview. $\mathrm{com} / \mathrm{p}=36382$

Siddiqui, K. (2018b). "U.S. - China Trade War: The Reasons Behind and its Impact on the Global Economy", The World Financial Review, November/December, pp. 62-68. ISSN 1756-3763. Retrieved from http://www.worldfinancialreview.com/?p=36411

Siddiqui, K. (2019). "The US Dollar and the World Economy: A critical review", Athens Journal of Economics and Business. Forthcoming.

SIPRI. (2018). The independent Resource on Global Ssecurity, Stockholm. Retrieved from https:// www.sipri.org/research/armament-and-disarmament/arms-transfers-and-military-spending/ military-expenditure 
Wade, R. (2009). From Global Imbalances to Global Reorganisations. Cambridge Journal of Economics, 33(4), 539-562. DOI: 10.1093/cje/bep032.

Wade, R. (2017). The American Paradox: Ideology of Free Markets and the Hidden Practice of Directional Thrust. Cambridge Journal of Economics, 41: 859-880. DOI: 10.1093/cje/bew064.

Wien, B. R. (2010). "US Capital Productivity Decline Must be Reversed", Financial Times, 17 February, London.

Willett, T. D., \& E. M. P. Chiu. (2012). "Power Relations and the Political Economy of Global Imbalances", Global Economic Review, 41(4), 341-360.

Wolf, M. (2008a). "Comments on Global Imbalances", Financial Times, p. 13, 7 October, London.

Wolf, M. (2008b). "Why It is So Hard the Keep the Financial Sector Caged", Financial Times, 6 February, London.

World Bank. (2017). Global Economic Prospects: A Fragile Recovery, June. World Bank: Washington DC-USA. 
